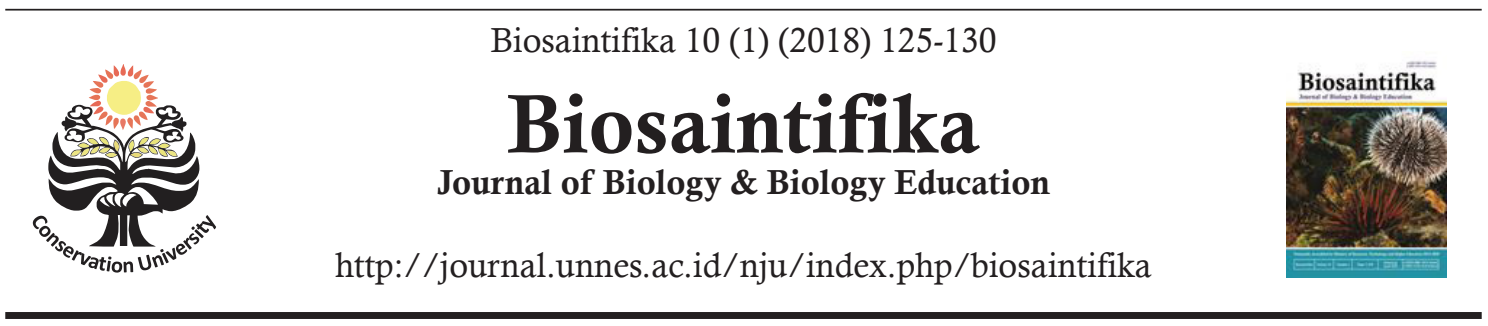

\title{
The Effect of Red Fruit Oil (Pandanus conoideus) to the Histophysiology of Rat (Rattus norvegicus) Liver Exposed to Cigarette Smoke
}

\author{
${ }^{\circledR}$ Albertina Dhiu Kio, Tyas Rini Saraswati, Enny Yusuf Wachidah Yuniwarti
}

DOI: 10.15294/biosaintifika.v10i1.12822

Department of Biology, Faculty of Science and Mathematics, Universitas Diponegoro, Indonesia

\section{History Article}

Received 18 January 2018

Approved 28 March 2018

Published 30 April 2018

\section{Keywords}

Cigarette smoke; Liver Histophysiology; Red fruit oil

\begin{abstract}
Free radicals in cigarette smoke may interfere the balanced of body molecules and cause the damage of hepatic cells. This issues may be prevented by using red fruit oil (Pandanus conoideus $\mathrm{L}$ ) due to its antioxidant content. This study aimed to evaluate the structure and physiological conditions of liver when the red fruit oil given to the rat that exposed by cigarette smoke. This study carried out for 35 days with female white rats as the sample. The samples were 20 female white rats divided into four groups: P0 (negative control), P1 (positive control), P2 (exposed by cigarette smoke with administration of red fruit oil $0,1 \mathrm{ml} / \mathrm{BB}$ ), P3 (exposed by cigarette smoke with administration of red fruit oil 0,2 ml/weight). The data of ALT, AST, cell diameter, and hepatic weight were analyzed by using analysis of variants (ANOVA). The results showed that administration of red fruit oil containing antioxidants can reduce levels of ALT, AST, hepatocyte diameter, and increase liver weight, although the difference is not significant compared to the control group and does not affect the eating and drinking behavior so as not to affect the body's metabolism. The conclusion of red fruit oil can reduce ALT, AST, hepatocyte diameter and increase hepatic weight due to exposure to cigarette smoke, although the difference is not significant to the control group, and does not affect the eating and drinking behavior, so good for consumption because it gives a beneficial effect on health liver organ.
\end{abstract}

\section{How to Cite}

Kio, A. D., Saraswati, T. R., \& Yuniwarti, E. Y. W. (2018). The Effect of Red Fruit oil (Pandanus conoideus) to the Histophysiology of Rat (Rattus norvegicus) Liver Exposed to Cigarette Smoke. Biosaintifika: Journal of Biology \& Biology Education, $10(1), 125-130$.

(C) 2018 Universitas Negeri Semarang $\bowtie$ Correspondence Author:

J1.Prof.H.Soedarto, S.H.Tembalang, Semarang, Jawa Tengah 50275

E-mail: atin_dhiukio15@yahoo.com
p-ISSN 2085-191X e-ISSN 2338-7610 


\section{INTRODUCTION}

Based on data of World Health Organization (WHO), in 2013 the number of death reach 6 million in the world as the results of smoking (Golli et al., 2016). The cigarette smoke contain more than 4.000 chemicals and hundreds of them were toxic substances for body. Any substantial finds in cigarette e.g. nicotine, tar, carbonmonoxy, formaldehyde, benzene, cadmium, timbale/lead, ammonia, PAH (Polynuclear Aromatic Hydrogen), phenol, carbonyl, chlorine dioxin, furan, and radical (Goniewicz et al., 2014). The entrance of cigarette smoke into the body is through the inhalation.

The compounds produced by cigarette smoke contains free radical (Feitosa et al., 2016). Free radical of cigarette smoke are derived from two different fractions i.e. tar phase and smoke phase.. The gas phase of cigarette smoke produces the most reactive free radical such as oxygen and carbon radicals. The effect of free radical caused the pathology conditions indicated with system injuries to the DNA injuries (Rahimah $e t$ al., 2009).

Liver includes to the organs that is vulnerable to the free radical (Pavlovic et al., 2007). The damages of liver caused by cigarette smoke can be recognized by check-up enzyme category transaminase, Aspartate Aminotransferase (AST) enzyme or well-known as Glutamate Oxaloacetate Transaminase (GOT) and Alanine Aminotransferase (ALT) enzyme or well-known as Glutamate Pyruvate Transaminase (GPT). Both of these enzymes will come out from hepatic cell if the hepatic cell is damage, and as the results, increased the levels in blood serum (Hidayat et al., 2013).

The efforts made to prevent the damage of hepatic resulted by free radical of cigarette smoke with red fruit oil anointment (Pandanus conoideus $\mathrm{L}$ ) which contain the antioxidant. Red fruit oil (Pandanus conoideus L), is the results of the extraction of red fruit plants which contain the active compounds of carotenoid $12.000 \mathrm{ppm}$, $\beta$-carotene $700 \mathrm{ppm}$, tocopherol $11.000 \mathrm{ppm}$, oleic acid $74.6 \%$, linoleic acid $8 \%$, linolenic acid $8.36 \%$ and some minerals such as $\mathrm{Ca}$ and $\mathrm{Fe}$ in suffice amount (Budi \& Paimin, 2005). The mechanisms of antioxidant in red fruit oil are to inhibit the formation of free radical, and as a mediator in terms to neutralize the free radical that might had formed as well as reduce the potency of free radical in oxidation reaction and inhibit the oxidative enzyme for example cytochrome $\mathrm{P}-450$. The inhibition of free radical will protect the normal hepatocyte from the damage and optimize the hepatic cells to regenerate. Based on the summary above, the study was carried out to evaluate the potency of red fruit oil (Pandanus conoideus $\mathrm{L}$ ) to the histophysiology hepatic rat (Rattus norvegicus) exposed by cigarette smoke. Thus, this study is useful to increase knowledge about the potential of red fruit oil (Pandanus conoideus L) as an antioxidant in providing protective effect on the structure and function of liver due to exposure of free radical cigarette smoke.

\section{METHODS}

The samples use in this study were female white rats type Rattus norvegicus (weight 150 $\pm 200 \mathrm{~g}$.) with the age of 2.5 months. The rats were placed in standard environment condition (temperature $26-28{ }^{\circ} \mathrm{C}$, humidity $60-80 \%$ ). Twenty female white rats were divide randomly into five trial groups as follows: (a) P0 (without cigarette smoke and red fruit oil), (b) P1 (exposed to cigarette smoke without the administration of red fruit oil), (c) P2 (cigarette smoke + the administration of red fruit oil $0.1 \mathrm{ml} \mathrm{BB} /$ day), (d) P3 (cigarette smoke + the administration of red fruit oil $0.2 \mathrm{ml} \mathrm{BB} /$ day).

The treatment of exposed by cigarette smoke were carried out after the samples try to acclimate during a week. Cigarette used in this study was a clove (kretek) cigarette with the amount of one cigarette per day. Each treatment with cigarette smoke was conducted in treatment cage. The base of cigarette takes into the plastics bottle that has been modifications before burn the tip of cigarette. Then, the cigarette keeps into the treatment cage by placing in the modification place in each cage. The cage's roof was covered by gauze and glass, and also equipped with a gap for air circulation. After the last cigarette burns out, the samples were taken out from their treatment cage. Treatment with cigarette smoke was conducted every day for one week start at 10:00 PM until finish.

Measurement of ALT and AST activities for all groups were conducted in last treatment. The bloods were taken through the heart and accommodated in Eppendorf tube, then centrifuged with $6500 \mathrm{rpm}$ for about 10-15 minutes. The ALT and AST content were determined by kinetic method of UV International Federation of Clinical Chemistry (IFCC). The reagents used were ABX ALT and ABX AST with ABX Pentre. The activity of serum ALT and AST was conducted as the biochemical signal of hepatocellular damage. The making process of preparation was 
conducted by the way rats dissected and took their hepatic organ. Liver organ then was put into the BNF $10 \%$. The following steps were dehydrating process by using alcohol with a high concentration $(70 \%, 80 \%, 90 \%$, and absolute alcohol) followed by clearing process with xylol, embedding and blocking process by using the paraffin. Then, the sectioning process was conducted by cutting paraffin block with the thickness of about 5-6 millimicrons. Colouring process was conducted by using Haematoxylin-Eosin (HE). The observation was conducted under the light microscope with the magnification of $10 \times 40$. The measurement of the hepatocyte liver diameter was determined by calculating the averages of the diameter with measurement results of the longest and the shortest part of the hepatocyte. The data as the results of the study were then analysed by Analysis of Varian (ANOVA) on the $95 \%$ of confidence level.

\section{RESULTS AND DISCUSSION}

The effect of red fruit (Pandanus conoideus L) administration to the female white rats (Rattus norvegicus) influenced by the expose of cigarette smoke with a dose of one cigarette each day during a week to the content activity of serum ALT and AST showed no significant change $(\mathrm{P}>0.05)$ between negative control $(\mathrm{P} 0)$ which is, treatment to rats without cigarette smoke and red fruit oil and treatment to rats with cigarette smoke without red fruit oil (P1), and also there are no difference between the treatment groups with doses of red fruit oil $0,1 \mathrm{ml}(\mathrm{P} 2)$, treatment groups with doses of red fruit oil $0.2 \mathrm{ml}$ (Table 1 and 2).

The average of ALT and AST content in
P0 group was assumed as a normal level and can be used as the standard for comparison. According to Table 1 , the averages of highest content of ALT find in group P1 and the lowest content of ALT find in group P2. The averages of highest content of AST find in group P1 and the lowest content of AST find in group P0. The use of cigarette smoke aims to increase free radical until the content of antioxidant endogenic unable to control free radical and body needs antioxidant exogenic.

Normal content of AST in rats is 45.7-80.8 $\mathrm{U} / \mathrm{L}$. Normal content of ALT in rats is 17.5-30.2 $\mathrm{U} / \mathrm{L}$ (Gad, 2007). AST value (115.40 U/L) and ALT value (56.60 U/L) of control groups gathered from this study were found higher than the normal content. This issue comes up because the use of cigarette smoke does not damage the necrosis of hepatocyte cells and the content of enzyme transaminase still secrecy in normal amount and does not increase. ALT is the more specific indicator damaged of hepatic cell, while AST is the indicator damaged of hepatic cell, muscle cells order, muscle cells heart, and kidney cell. The averages of lowest content of both ALT and AST find in group P2 with red fruit anointment doses $0,1 \mathrm{ml}$. The characteristics of red fruit oil as an antioxidant helps to reduce the effect of free radical produced by cigarette smoke.

Free radical produced by cigarette smoke will enter the lung through the circulatory system. Lung will pump up the blood over the bodies include liver. Through the liver, the process of metabolism and dihedrals occur involves the cytochrome P-450 (Herliansyah, 2001). Free radical redundant on the bodies will affect the oxidative stress. Oxidative stress is condition where the

Table 1. Average level of ALT and AST enzymes content after the administration of red fruit (Pandanus conoideus Lam) as the results of cigarette smoke exposure.

\begin{tabular}{ccccc}
\hline \multirow{2}{*}{ Variables } & \multicolumn{4}{c}{ Treatments } \\
\cline { 2 - 5 } & \multicolumn{1}{c}{ P0 } & \multicolumn{1}{c}{ P1 } & \multicolumn{1}{c}{ P2 } \\
\hline ALT (U/L) & $56.60 \pm 37.58$ & $58.00 \pm 21.45$ & $36.60 \pm 23,29$ & $48.00 \pm 4.69$ \\
AST (U/L) & $115.40 \pm 33.73$ & $172.40 \pm 71.60$ & $116.80 \pm 23,71$ & $127.60 \pm 20.63$ \\
\hline
\end{tabular}

Description: The effect of red fruit administration to the activity of ALT and AST enzymes showed no significant change $(\mathrm{P}>0.05)$

Table 2. Average hepatocyte cell diameter and liver weight of rats exposed to cigarette smoke after administration of red fruit oil (Pandanus conoideus $\mathrm{L}$ )

\begin{tabular}{|c|c|c|c|c|}
\hline \multirow[b]{2}{*}{ Variables } & \multicolumn{4}{|l|}{ Treatments } \\
\hline & P0 & $\mathrm{P} 1$ & $\mathrm{P} 2$ & P3 \\
\hline Diameter Hepatocyte Cells $(\mu \mathrm{m})$ & $17.09 \pm 0.66$ & $17.81 \pm 2.85$ & $16.06 \pm 3.27$ & $16.86 \pm 1.09$ \\
\hline Hepatic Weight (g) & $8.15 \pm 1.14$ & $8.49 \pm 1.57$ & $9.01 \pm 1.62$ & $8.49 \pm 1.36$ \\
\hline
\end{tabular}

Description: The effect of red fruit administration to the hepatocyte cells diameter showed no significant change $(\mathrm{P}>0.05)$ 
free radical and the antioxidant defence system imbalance (Stevonson et al., 2005).

There are several mechanisms of antioxidant work in the body such as inhibiting the formation of free radical, working as amediator in terms of neutralise the free radical that may had formed, reducing the potency of free radical in oxidase reaction, and inhibiting the oxidative enzyme for example cytochrome P-450. The inhibition of free radical will protect normal hepatocyte from the damage and optimize the hepatic cells to regenerate.

Enzyme AST is a parenchyma heart enzyme mostly found in muscle, heart, kidney, and brain. Carl (2006) mentioned that a high damage of liver with a high content of AST and ALT generally show no increase. Even the content of both enzyme was decreased because of the widely damage of hepatocyte cells. The same idea was mentioned by Panjaitan et al., (2011), where in the level of widely damage, the availability of both enzyme become lower because the ability of hepatic cell to synthesize the enzyme is decreased.

The measurement of of hepatocyte cells diameter shows the result real unchanged $(\mathrm{P}>0.05)$. Treatment with red fruit oil showed no significant change of diameter hepatocyte cells compared to the negative control (P0) which is, treatment to rats without cigarette smoke and red fruit oil and treatment to rats with cigarette smoke without red fruit oil (P1), and also there are no difference between the treatment groups with doses of red fruit oil $0,1 \mathrm{ml}(\mathrm{P} 2)$, treatment groups with doses of red fruit oil $0.2 \mathrm{ml}$.

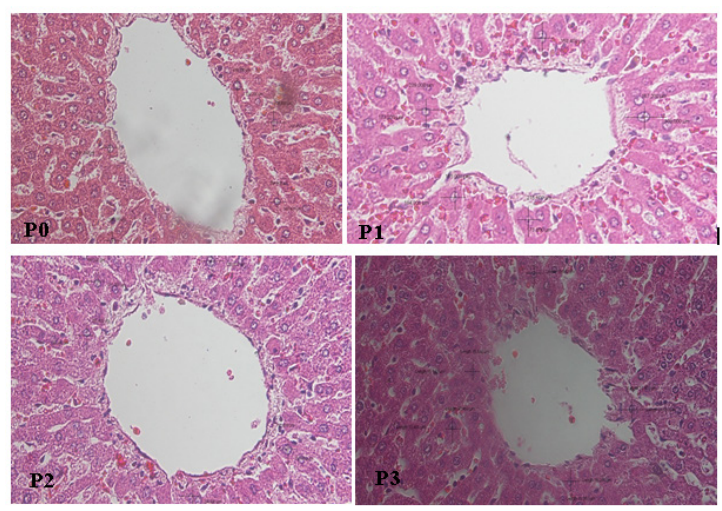

Figure 1. Photomicrograph of hepatic cells with Hematoxylin-eosin (HE) staining observed by using 400x magnification showed no significant difference $(\mathrm{P}>0,05)$.

Diameter of hepatocyte cells which real unchanged due to the high antioxidant contains in the red fruit oil. The tocopherol in red fruit oil helps to improve body immune system and the result is the mortality of body cells decrease. Tocopherol also helps to form new cells to replace the broken cells. Beta-carotene also has the role as an antioxidant and used to catch the reactive compounds and prevent the occurrence of chain reaction affected by free radical of cigarette smoke.

Liver is an organ with fast regeneration. The disposal of any hepatic cells in case of dead or diseased cells will be replaced with new hepatic cells (Michalopoulos, 2007). Liver contains intra hepatic stem cells, the precursor of the replication of hepatocyte cells. The replication of these hepatocyte cells will help to regenerate the cells in order the growth and the development of hepatic damage by disorder resolved quickly (Fausto \& Campbell, 2003). The effect of antioxidant on red fruit oil help regenerates the hepatic cells damage by disorder of cigarette smoke during a week.

The result analysis showed that of red fruit administration (Pandanus conoideus Lam) to the female white rats (Rattus norvegicus) exposed to cigarette smoke with one cigarette each day during a week to the hepatic weight showed no significant difference $(P>0.05)$. Treatment with red fruit oil showed no real unchanged between the group of negative control, positive control, and treatment. This issue comes up because the expose of cigarette smoke still acute and unable to give toxics effect, because the ability of hepatocyte cells to regenerate fast to replace the broken hepatocyte due to the cigarette smoke with new hepatocyte cells.

In the other hand, the replacement occurs in hepatocyte is categorized as a small disorder in normal condition, so that the metabolism process of hepatic still continue normally. The organ in gastrointestinal tract such as intestine is still capable to fix the damage caused by the cigarette smoke exposure. Intestine is the organ in which it's cells have the capability to regenerate quickly, so the effects caused by the exposure of cigarette smoke seem unreal. The condition of fast regeneration gives animpact on the absorption process which runs normally. The normal activity of gastrointestinal tract does not affect the replacement of real body weight.

The result of analysis showed that the administration of red fruit oil (Pandanus conoideus Lam) on female white rat (Rattus norvegicus) exposed to cigarette smoke give no significant difference $(\mathrm{P}>0.05)$ to the feed intake. Average feed intake in mice after treatment was $11.60 \mathrm{~g} /$ day $-13.20 \mathrm{~g} /$ day. The consumption of feed and drink were governed by one part of the autono- 
Table 3. The average of consumption feed after the treatment of red fruit oil (Pandanus conoideus Lam).

\begin{tabular}{lllll}
\hline \multirow{2}{*}{ Variables } & \multicolumn{2}{l}{ Treatments } & P2 & P3 \\
\cline { 2 - 5 } & P0 & P1 & $11.60 \pm 2.19$ & $12.00 \pm 1.73$ \\
\hline Feed Consumption (g / day) & $11.60 \pm 1.95$ & $13.20 \pm 2.17$ & $11.64 \pm 3.93$ & $10.05 \pm 3.43$ \\
\hline Drink Consumption (ml / day) & $8.79 \pm 1.80$ & $10.10 \pm 0.95$ & $11.6 \pm$
\end{tabular}

Description: The effect of red fruit administration to the fed consumption and drink consumption given to the rats showed no significant change $(\mathrm{P}>0.05)$

mic nervous system, the hypothalamus, which acts as the regulator of eating and drinking. The hypothalamus regulates food intake in two regions: the lateral area of the cinereum tuber which acts as the center for hunger, while satiety center on the ventromedial nucleus area (Saraswati et al., 2009).

The non-significant different in feed consumption between the treatment and control group and the treatment was due to several factors i.e. the dose of red fruit oil and the exposure time of cigarette smoke. The treatment of red fruit oil with dose of $0.1 \mathrm{ml} / \mathrm{BW} /$ day and dose of $0.2 \mathrm{ml} / \mathrm{BW} /$ day and exposure of cigarette smoke as many as one cigarette per day for seven days is not accumulated in the body, so that the transfer of neurotransmitter has not been disturbed yet, and the regulation of food center was running normally. The second possibility is the impact of exposure to secondhand smoke is still acute and has not caused damage to the organ so that the metabolic process is not disturbed, but allegedly until the level of suppression of cell or tissue function. The third possibility is the ability of the body of a mouse that is capable of absorbing and eliminating various metabolite results, so that the food center regulation system in the hypothalamus can function normally.

The result of analysis showed that the administration of red fruit oil (Pandanus conoideus Lam) on female white rat (Rattus norvegicus) exposed to cigarette smoke give no significant difference $(\mathrm{P}>0.05)$ to the water intake (drink). Average water intake in mice after treatment was $8.79 \mathrm{ml} /$ day $-11.64 \mathrm{ml} /$ day which means that there is no significant difference. Consumption of drinking water is controlled by cytochrome enzymes that are widely present in the liver, because in ward toxic substances it takes a lot of water so that metabolites from toxic substances can be eliminated from the body. Increased water intake is also influenced by the balance of body fluids. The body part that plays a role in the osmolarity control system is in the anteroventral edge of the third ventricle. If there is a change in cell osmolarity there will be signals received by the system and by the third ventricular anteroventral system, the sig- nal will be sent to the anterolateral portion of the preoptic nucleus in the hypothalamus. This signal is then translated as a desire to drink (Yuniwarti \& Saraswati, 2003).

The consumption of drinking water which is not different between control and treatment groups indicated that giving of $0.1 \mathrm{ml} / \mathrm{BW} /$ day and $0.2 \mathrm{ml} / \mathrm{BW} /$ day doses of did not cause cell osmolarity. This is because the signal received by the hypothalamus is not inhibited so that the effects of substances or toxic compounds produced from exposure of cigarette smoke cause the consumption of drinking is not significantly different.

Based on the results, it can be concluded that the administration of red fruit oil can reduce the ALT, AST, hepatocyte diameter and increase the liver weight of rats exposed to cigarette smoke. Although the difference is not significant to the control group, and does not affect the eating and drinking behaviour. So it is good for consumption because it gives a beneficial effect on health hepatic organ..

\section{CONCLUSION}

The conclusion is that red fruit oil tend to reduce the ALT, AST and hepatocyte diameter as well as increase the liver weight of rats exposed to cigarette smoke, although the difference is not significant to the control group, and does not affect the eating and drinking behaviour.

\section{ACKNOWLEDGMENT}

The writer thanks to Pemda Kab. Ngada, Flores, NTT and Dr. Enny Yusuf W. Yuniwarti, MP for financially support this study.

\section{REFERENCES}

Budi, I.M., \& Paimin, F.R. (2005). Buah Merah. Jakarta: Penebar Swadaya.

Carl, A., Edward, R. \& David, E. (2006). Clinical Chemistry a Molecular Diagnostic II. Philadelphia (US): Elsevier.

Fausto, N. \& Campbell, J. S. (2003). The Role of He- 
patocytes and Oval Cells in Liver Regeneration and Repopulation. Mechanisms of Development. Journal of Animal and Veterinary Advances. 120(1), 117-130

Feitosa, E.M., Okuro, R.T., Ribeiro, V.P., Lanzetti M., Barroso, M.V., Zin, W.A., Porto, L.C., Gitirana, L.B., \& Valenca, S.S. (2016). Eucalyptol Attenuates cigarette smoke-induced acute Lung Inflammation and Oxidative Stress in the Mouse. Pulmonary Pharmacology \& Therapeutics Journal, 41(1), 11-18.

Gad, S.C. (2007). Animal Models in Toxicology. Boca Raton: CRC Press.

Golli, N.E., Dkhili H., Dallagi Y., Rahali D., Lasram M., Dhouib, I.B., Lebret M., Rosa, J.P., Fazaa, S.E., \& Asmi, M.A.E. (2016). Comparison Between Electronic Cigarette Refil Liquid and Nicotine on Metabolic Parameters in Rats. In ternasional Life Sciences Journal, 146(1), 131-138.

Goniewicz, M.L, Knysak J., Gawron M., Kosmider L., Sobczak A., Kurek J., Prokopowicz A., Czapla M. J., Dulewska C.R., Havel C., Jacob P., \& Benowitz N. (2014). Levels of Selected Carcinogens and Toxicants in Vapor From Electronic Cigarettes. Tob. Control, 23(1) 133-139.

Herliansyah. (2001). Chewing Haliah Sheds Disease. Journal of Malaysian Research.UKM Malaysia, 12(1), 45-57.

Hidayat, A., Christijanti, W. \& Marianti, A. (2013). Effect of Vitamin E Against SGPT and SGOT levels Strain Wistar Rats exposed to Lead. (2013). Biosaintifika: Journal of Biology \& Biology Education, 2(1), 16-21.
Michalopoulos, G.K. (2007). Liver regeneration. Journal Cell Physiology, 213(2),286-300.

Panjaitan, R.G.P., Manalu, W., Handharyani, E., \& Chairul. (2011). Hepatoprotective Activities Methanol Extract of Roots Pasak Bumi and Fractions of Derivatives. Veterinary Journal, 12(4), 319-627.

Pavlovic, V., Dusica, P., Gordana, K., Dusan, S., Tatjana, J.S., Snezana, C, \& Dragana, V.( 2007). Effect of Monosodium Glutamate on Oxidative Stress and Apoptosis in Rat Thymus Mol Cell Biochem 303(1), 161-166.

Rahimah, S.B., Sastramihardja, H.S., \& Sitorus, T.D. (2009) Antioxidant Effects Of White Oyster Mushroom At Malondialdehid Level And Lung Surface Density Of Rats Exposed to Cigarette Smoke. Bandung: Department of Pharmacology Faculty of Medicine Padjadjaran Bandung, 42(4),195-202.

Saraswati,T.R., Indraswari, E., \& Nurani. (2009). Effects of Formaldehyde, Diazepam and Alcoholic Beverages on Feed Consumption, Drinking and Body Weight Mus musculus. Journal of Science \& Mathematics, 17(3), 141-144.

Stevonson, C. S., Koch, L.G., \& Britton, S.L., (2005). Aerobic capacity, oxidant stress and cronic obstructive pulmonary disease-a New take on an old hypothesis. Journal Pharmakologi \& Theurapeutics. 1(1),71-82.

Yuniwarti, E.Y. \& Saraswati, T.R., (2003). Textbook Endokrinologi. Jurusan Biologi FsMIPA UNDIP. 